\title{
Determination of Zinc levels in Healthy Adults from the West of Algeria by Differential Pulse Anodic Stripping Voltammetry
}

\section{Tarik Attar $^{a^{*}}$, Nouria Dennouni-Medjati ${ }^{\mathrm{b}}$, Yahia Harek ${ }^{\mathrm{a}}$ and Lahcene Larabi ${ }^{\mathrm{a}}$}

`Laboratoire de Chimie Analytique et d’Electrochimie, Département de Chimie, Faculté des Sciences, Université Abou Bekr Belkaid, 13000, Tlemcen, Algeria.

${ }^{b}$ Laboratoire Antibiotiques, Antifongiques, Physico-chimie, Synthèse et Activité biologique, Département de Biologie, Université Abou Bekr Belkaid, Tlemcen 13000, Algeria.

* Corresponding author: E-mail address: t_attar@mail.univ-tlemcen.dz att.tarik@gmail.com

\begin{abstract}
An electroanalytical method has been developed for the determination of zinc in whole blood by differential pulse anodic stripping voltammetry (DPASV) on a hanging mercury drop electrode (HMDE). The best conditions were found to be electrolyte support perchloric acid $0.02 \mathrm{M}$, an accumulation potential of $-1150 \mathrm{mV}$, and an accumulation time of $60 \mathrm{~s}$. The optimum value of stirring rate was determined to be $400 \mathrm{rpm}$. The correlation coefficient and relative standard deviation were 0.9999 and $3.96 \%$ respectively with a detection limit of $0.86 \mu \mathrm{g} \mathrm{L}^{-1}$. Zinc levels in whole blood samples of 53 healthy subjects living in Tlemcen (west Algeria).
\end{abstract}

\section{Keywords}

Zinc; whole blood; Analytical Methods; Differential pulse anodic stripping voltammetry; Hanging mercury drop electrode.

\section{Academic Discipline And Sub-Disciplines}

Analytical Chemistry

\section{SUBJECT CLASSIFICATION}

Chemistry Subject Classification

\section{TYPE (METHOD/APPROACH)}

Experimental study

\section{$\underline{\text { Council for Innovative Research }}$}

Peer Review Research Publishing System

Journal: Journal of Advances in Chemistry

Vol. 6, No. 1

editor@cirworld.com

www.cirworld.com, member.cirworld.com 


\section{INTRODUCTION}

Environmental pollution has given rise to concern about the accumulation of heavy metal in human body [1]. In order to trace the exposure and absorption of such element, biological indicators such as blood, hair, and urine are often analyzed [2]. Zinc is one of the important trace elements related to health and disease. It plays an important role in human growth; it has a recognized action on more than 300 enzymes, by participating in their structure or in their catalytic and regulatory actions [3,4]. It is a structural ion of biological membranes and it's closely related to protein synthesis [5, 6]. Zinc deficiency has long been recognized as a role-playing in a number of physiological disorders, including dermatologic conditions such as eczema, acne, and psoriasis [7-11]; poor wound healing [12-14 ]; growth retardation [15-17]; delayed sexual maturity [18]; hypogeusia and chronic immunodeficiency [19]. In most cases, abnormally low levels of zinc appear to involve a malfunction of the metal-binding protein metallothionein [20, 21]. The choice of a method will depend in particular on nature of the studied medium, amongst elements to be proportioned and their concentrations, amongst analyses to be carried out, of the speed required of the analysis, the precision imposed on proportioning and finally of the equipment which one lays out or which one can lay out. The electrochemical methods have many advantages compared with the spectrometric methods, the equipment being less expensive and measurements being able to be realized in difficult mediums of access [22]. These methods ensure the transformation of a concentration of species into solution into an electric quantity measured by means of simple mathematical relations. Among the electrochemical methods most recent, the stripping voltammetry is a precise, significant and selective method electrochemical [23]. The objective of this work is to study the influence of the principal experimental parameters on the current of stripping, namely the effect of electrolyte support, potential of accumulation, the time of deposit and stirring rate of the solution in order to determine the concentration of the zinc dissolved in whole human blood.

\section{Experimental}

\subsection{Apparatus}

Anodic stripping voltammetry measurements were performed using a commercially available TraceLab 50 trace analysis system. It consists of POL150 polarographic analyzer, MDE150 polarographic stand and TraceMaster 5 software (Radiometer Analytical S.A, France). The three electrodes system consists of a working hanging mercury dropping electrode (HMDE) that was renewed prior to each measurement, a platinum auxiliary electrode and $\mathrm{Ag} \mid \mathrm{AgCl}$ saturated with $\mathrm{KCl}$ as reference electrode.

\subsection{Reagents}

All chemicals used were of analytical-reagent grade or the highest purity available. Aqueous solutions were prepared by dissolving a certain amount of chemicals into high-purity deionized (DI) water (MilliQ water system). Acids used for the analysis, the nitric acid (69.5\%, Fluka) and the perchloric acid (70-72\%, Merck). Stock solutions of zinc (1000 ppm, atomic adsorption standard, Aldrich), were diluted daily as required.

\subsection{Sample digestion}

A $1.0 \mathrm{ml}$ of whole blood in a long-necked $50 \mathrm{ml}$ flask, $4.0 \mathrm{ml}$ of acid mixture $\left(3 \mathrm{ml} \mathrm{HNO}_{3}\right.$ and $\left.1 \mathrm{ml} \mathrm{HClO}_{4}\right)$ was added in flask. The temperature is maintained with $150^{\circ} \mathrm{C}$ during 4 hours and then the temperature is fixed at $200^{\circ} \mathrm{C}$ until quasi total evaporation of the contents [24]. After cooling, we add the same mixture of acids to the residue, then we let evaporate until obtaining a dry residue [25]. This residue is taken again by $5 \mathrm{ml}$ of nitric acid with $0.25 \%$ and preserved in polyethylene tubes $[26,27]$. In this case, the mixtures of strong acids used allow, in combination with high temperatures, to destroy the organic matter and to transform it into by-products of gas reaction, which are then eliminated under the hood. It is in fact necessary, to reduce the contaminations, to use quantities as weak as possible reagents.

\subsection{Voltammetric Measurement}

A $10 \mathrm{~mL}$ sample solution, containing of perchloric acid was transferred to the voltammetric cell and purged with nitrogen for $5 \mathrm{~min}$. The accumulation potential $(-1150 \mathrm{mV})$ was applied to a fresh mercury drop for $60 \mathrm{~s}$ while the solution was stirred. Following the accumulation period, the stirring was stopped, and after $20 \mathrm{~s}$ the second-order derivative linear scan voltammogram was recorded by applying a positive-going potential scan at $20 \mathrm{mV} \mathrm{s}^{-1}$. The concentration of zinc in the samples was determined using standard addition method. Reagent blanks were taken along with each batch of samples and the metal concentration observed in these blank samples were subtracted from the corresponding batch of field samples.

\section{Results and discussion}

\subsection{Effect of concentration of electrolyte support}

In a first step, the effect of concentration supporting electrolyte was investigated. Fig. 1 shows the influence of the concentration $\mathrm{HClO}_{4}$. The effect of electrolyte support on peak current was studied with concentration in the range from 0.01 to $0.1 \mathrm{M}$. A decrease in the current is observed when the concentration electrolyte support is higher than $0.02 \mathrm{M}$. Thus, the optimum concentration for further studies was fixed in $0.02 \mathrm{M}$. 


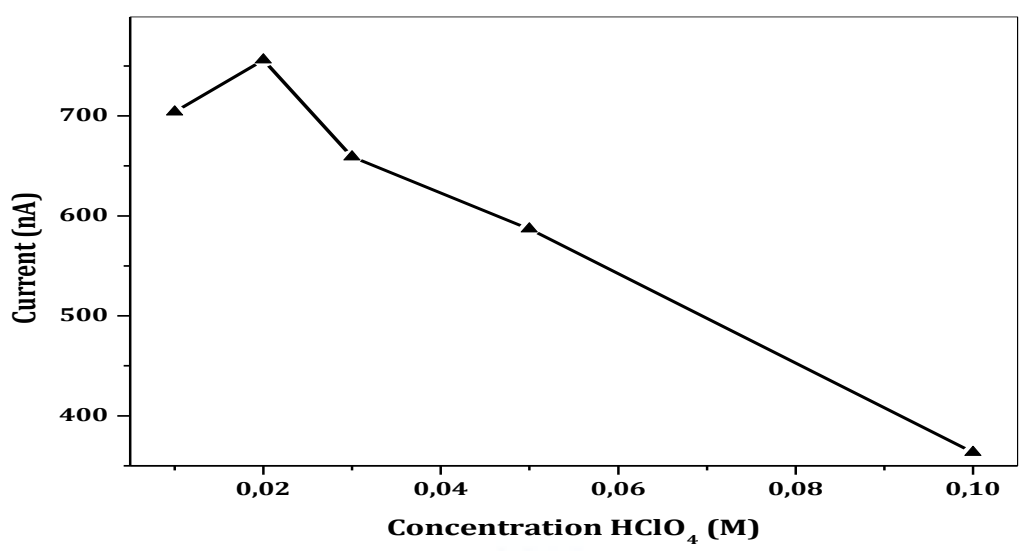

Fig. 1. Relationship between concentration of electrolyte support and measured current values. Conditions: solutions containing $70 \mu \mathrm{g} \mathrm{L}^{-1}$ of zinc; deposition potential is $-1150 \mathrm{mV}$; Stirring rate is $400 \mathrm{rpm}$ and accumulation time is $60 \mathrm{~s}$.

\subsection{Effect of deposition potential}

In the stripping procedure, the determination of the elements is based on the use of a deposition potential. The optimum deposition potential must be obtained. For this purpose, the deposition was carried out on the HMDE for $60 \mathrm{~s}$ at several selected deposition potentials. The relation between the peak current and the deposition potential is shown in Fig. 2. The effect of the accumulation potential on the peak current was examined over the range from -1200 to $-1050 \mathrm{mV}$. The peak current increased gradually with changing potential from -1200 to $-1150 \mathrm{mV}$, reached its maximum at $-1150 \mathrm{mV}$ and decreased at more positive potentials. Therefore, an accumulation potential of $-1150 \mathrm{mV}$ was used in all experiments.

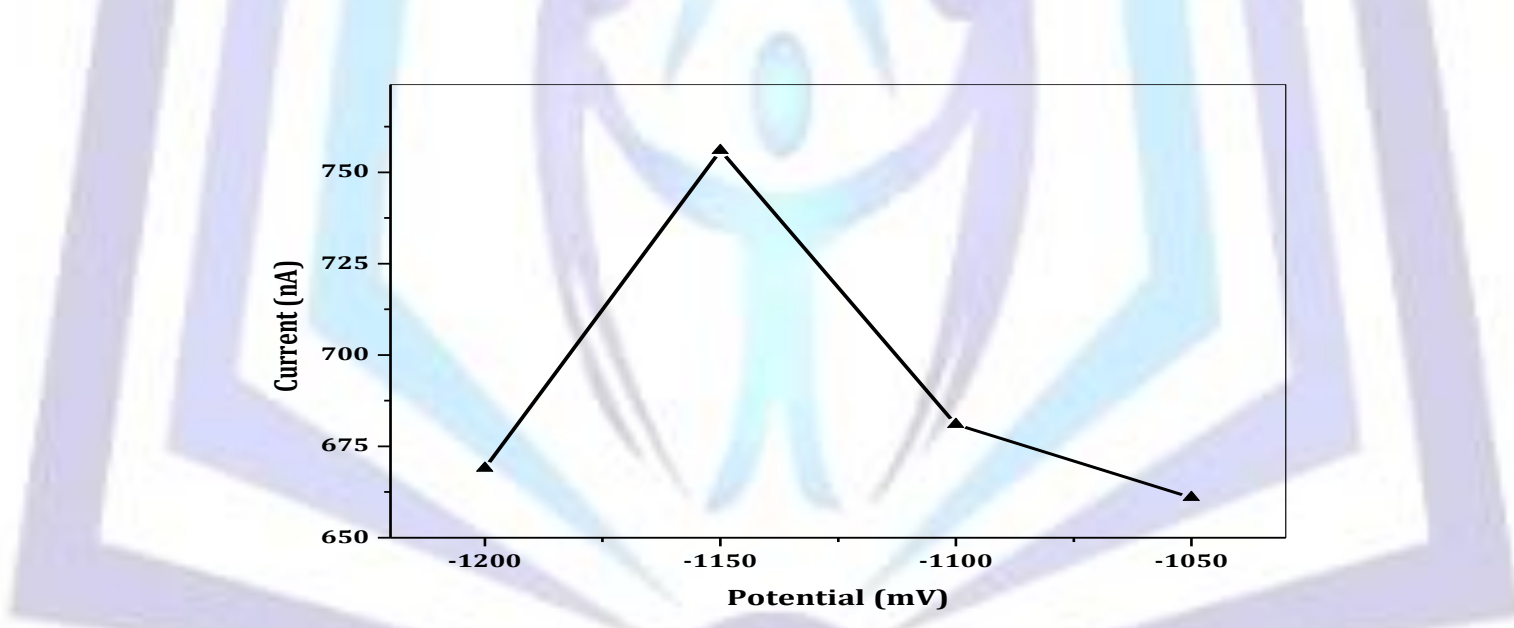

Fig. 2. Relationship between preconcentration time and measured current values. Conditions Fig.1.

\subsection{Effect of accumulation time}

The accumulation time is always important factor in stripping voltammetric analysis because of its prevailing influence on sensitivity and detection limit of the method [28]. The effect of accumulation time on the zinc peak current was studied in the $0-75 \mathrm{~s}$ range in solutions containing $70 \mu \mathrm{g} \mathrm{L}^{-1}$ of $\mathrm{Zn}$, as illustrated in Fig. 3 . It is seen that the peak current of the zinc increases linearly as accumulation time increases. At longer times the peak current decreased notoriously became almost constant, probably due to saturation in the surface of the mercury electrode. For succeeding studies an accumulation time of $60 \mathrm{~s}$ was chosen. 


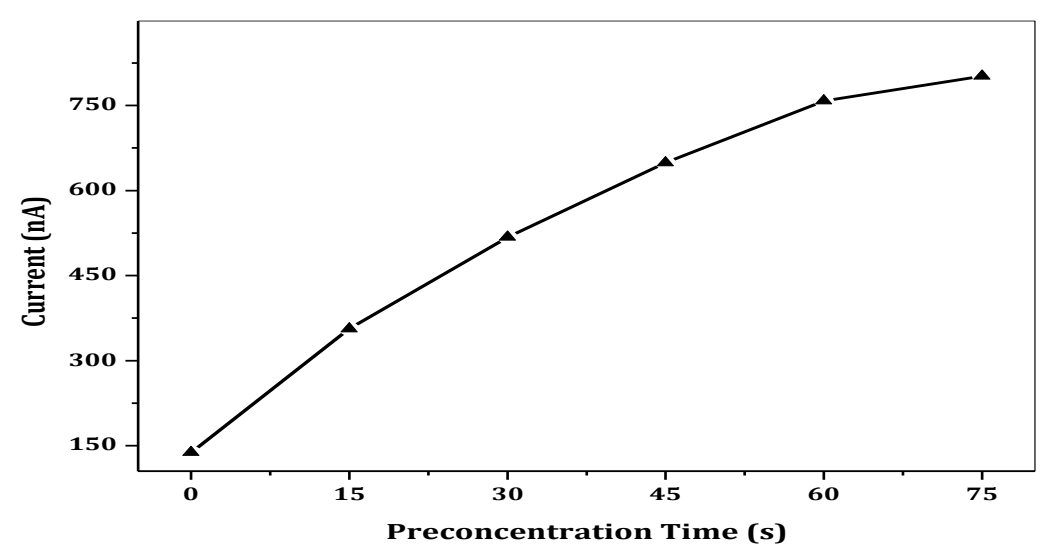

Fig. 3. Relationship between accumulation time and measured current values. Conditions Fig .1.

\subsection{Effect of stirring rate}

Stirring intensity is one of the important parameters that affect the accumulation efficiency. Agitation of the sample solution facilitated the mass transfer process. In present work, the samples were agitated at various stirring rates $(150,225,300,400$ and $525 \mathrm{rpm})$. The result showed that the current intensity efficiency was first improved with increased agitation rate before $400 \mathrm{rpm}$ and then decreases starting after this agitation rate (Fig.4). Hence, a stirring rate of $400 \mathrm{rpm}$ was chosen for further studies.

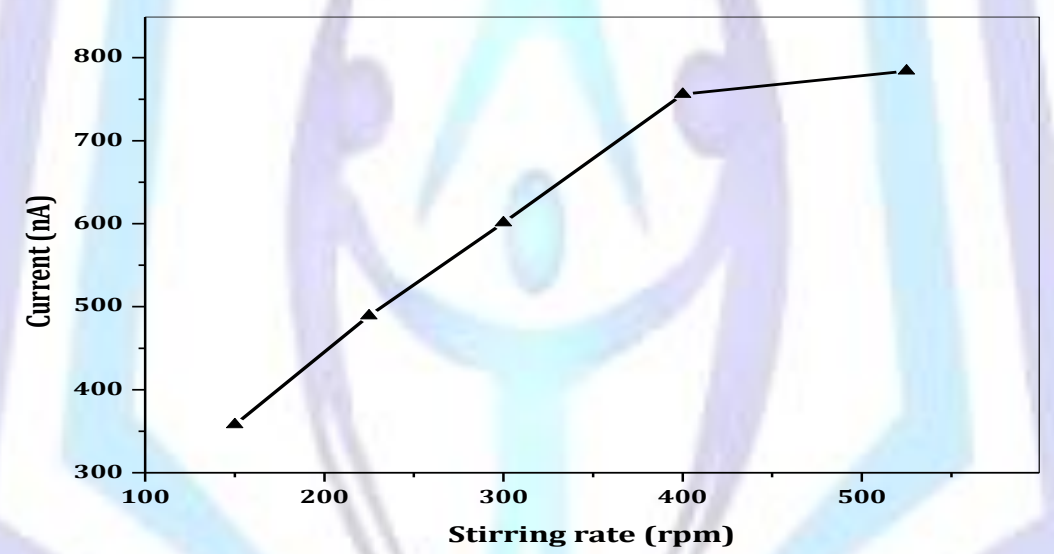

Fig. 4. Relationship between stirring rate and measured current values. Conditions Fig.1.

\subsection{Calibration data}

For the evaluation of the analytical parameters (the recovery percentage, standard deviation, accuracy and precision), a study of the influence of the concentration of the zinc was made in aqueous solution under the optimal conditions mentioned above. It is observed that the precision is $3.96 \%$. This is strong evidence that this method is precise and reproducible. Furthermore, the percentage recovery of the zinc determination was tested by measurement of a standard reference material, and by comparison of results obtained by ASV with those obtained by inductively coupled plasma sector field mass spectrometer (ICP-SFMS) for the same set of samples, seronorm (level 3,0512627) was used as the standard whole blood certified reference materials with the recommended concentration of zinc is $97.75 \%$ which is an indication that this method is accurate for zinc is $97.42 \%$. A linear response over the concentration range of $2.8710^{-3}$ to $1625 \mathrm{~g} \mathrm{~L}^{-1}$ zinc was observed under optimum conditions, with correlation coefficient of 0.9999 . The detection limit for zinc was found to be $0.86 \mathrm{\mu g} \mathrm{L}^{-1}$ estimated from 10 replicate determination of blank solution. This limit is better than coupling ICP-MS [29].

\subsection{Application to blood samples}

Blood zinc levels in female subjects ranged from 5001.981 to $8109.407 \mu \mathrm{g} \mathrm{L}^{-1}$ with a mean value of

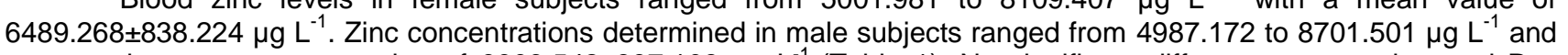
presented a mean concentration of $6903.542 \pm 897.108 \mathrm{\mu g} \mathrm{L}^{-1}$ (Table 1). No significant differences were observed $\mathrm{P}<$ 0.001 in blood zinc concentrations among women and men after applying to them the Student's t-test. 
Table 1 gives the results of means zinc concentrations, S.D.s, range, and $95 \%$ confidence intervals for the mean present at blood samples of healthy individuals grouped according to sex.

\begin{tabular}{lllll}
\hline Sex & $\mathrm{n}$ & Mean $\pm \mathrm{SD}\left(\mu \mathrm{g} \mathrm{L}^{-1}\right)$ & $95 \%$ Confidence & Range $\left(\mu \mathrm{g} \mathrm{L}^{-1}\right)$ \\
\hline Men & 27 & $6903.542 \pm 897.108$ & $6548.658 \pm 7258.426$ & $4987.172-8701.501$ \\
Women & 26 & $6489.268 \pm 838.224$ & $6150.298 \pm 6828.238$ & $5001.981-8109.407$ \\
All & 53 & $6700.313 \pm 885.313$ & $6456.144 \pm 6944.482$ & $4987.172-8701.501$ \\
\hline
\end{tabular}

The level concentration of zinc that we found in this study (mean $6700.313 \mu \mathrm{g} \mathrm{L}^{-1}$ ) that we found is very much in line with the values for an Italian population $6597 \mu \mathrm{g} \mathrm{L}^{-1}$ [30], Czech Republic population $6842 \mu \mathrm{g} \mathrm{L}^{-1}$ [31] and Chinese population $6399 \mathrm{\mu g} \mathrm{L}^{-1}$ [32]. As an application the figure below represents a voltammograms relating to the proportioning of zinc in the blood starting from the conditions which were optimized previously (Fig.5). The zinc concentration of this sample is equal $7169.263 \mu \mathrm{g} \mathrm{L}^{-1}$.

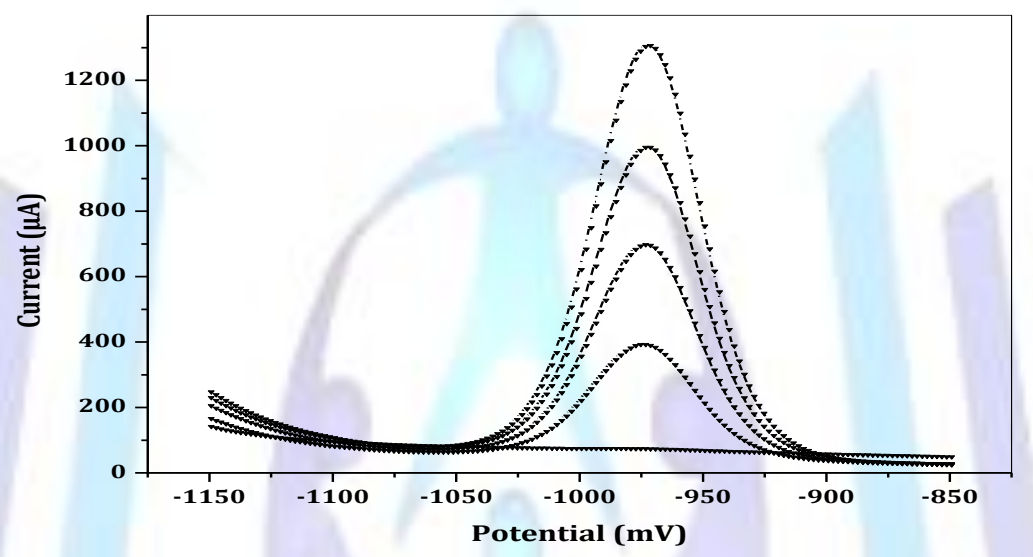

Fig. 5. Typical voltammograms for the determination of zinc contents in a whole blood sample by the standard addition method. Conditions: $E_{a c c}=-1150 \mathrm{mV} ; v=20 \mathrm{mV} \mathrm{s}{ }^{-1} ; t_{a c c}=60 \mathrm{~s}$.

\section{Conclusion}

The optimized method has been successfully applied to the determination of zinc in whole blood with good accuracy and precision. The proposed method is inexpensive and fast. The detection limit of $0.86 \mu \mathrm{g} \mathrm{L}^{-1}$ can be lowered further by increasing accumulation time. Acceptable agreement was found between the results obtained and the values of certified reference material. Moreover, and in the lack of bench-mark data regarding the standard rates of the blood of the trace elements in a healthy Maghrebian population, this work constitutes a first contribution to the establishment of a specific database to the town of Tlemcen.

\section{Reference}

[1] Tripathi, R.M., Raghunath, R., Mahapatra, S., Sadasivan, S. 2001 Sci Total Environ, 277, 161.

[2] Barany, E., Bergdahl, I.A., Brattelby, L.E., Lundh, T., Samuelson, G., Schutz, A., Skerfving, S., Oskarsson, A. 2002 Sci Total Environ, 286, 129.

[3] Yousef, M.I., El Hendy, H.A., El-Demerdash, F.M., Elagamy, E.I. 2002 Toxicology, 175, 223.

[4] Jansen, J., Karges, W., Rink, L. 2009 Journal of Nutritional Biochemistry, 20, 399.

[5] Cvijanovich, N.Z., King, J.C., Flori H.R., Gildengorin, G., Wong, H.R. 2009 Pediatric Critical Care Medicine, 10, 29.

[6] Heyland, D.K., Jones, N., Cvijanovich, N.Z., Wong, H. 2008 Journal of Parenteral and Enteral Nutrition, $32,509$.

[7] Bae, Y.S., Hill, N.D., Bibi, Y., Dreiher, J., Cohen, A.D. 2010 Dermatologic Clinics, 28, 587.

[8] Ricketts, J.R., Rothe, M.J., Grant-Kels, J.M. 2010. Clinics in Dermatology, 28, 615.

[9] Melinda, Jen., Albert, C. 2010 Clinics in Dermatology, 28, 669.

[10] White, G.M. 1999 Disease-a-Month, 45, 301.

[11] Thiboutot, D.M., 1997 Dermatologic Clinics. Dermatologic Clinics, 15, 97.

[12] Tabatabai, M.A., Eby, W.M., Singh, K.P. 2011 Mathematical and Computer Modelling, 53, 755. 
[13] Ruíz, C., Alegría, A., Barberá, R., Farré, R., Lagarda, M.J. 1998 Journal of Trace Elements in Medicine and Biology, 12, 91 .

[14] Williams, J.Z., Barbul, A. 2003 Surgical Clinics of North America, 83, 571.

[15] Salgueiro, M.J., Zubillaga, M.B., Lysionek, A.E., Caro, R.A., Weill, R., Boccio, J.R. 2002 Nutrition, $18,510$.

[16] Gaetke, L.M., McClain, C.J., Toleman, C.J., Stuart, M.A. 2010 The Journal of Nutritional Biochemistry, $21,147$.

[17] Takeda, A., Tamano, H. 2009 Brain Research Reviews, 62, 33.

[18] Piotrowska, K., Baranowska-Bosiacka, I., Marchlewicz, M., Gutowska, I., Noceń, I., Zawiślak, M., Chlubek, D., Wiszniewska, B. 2011 Nutrition, 27, 372.

[19] Fedeles, F., Murphy, M., Rothe, M.J., Grant-Kels, J.M. 2010 Clinics in Dermatology, 28, 627.

[20] Mocchegiani, E., Costarelli, L., Giacconi, R., Cipriano, C., Muti, E., Malavolta, M. 2006 Experimental Gerontology, 41, 1094.

[21] Wolfgang, M. 2008 Experimental Gerontology, 43, 363.

[22] Tercier, M,L., Buffle, J., Graziottin, F. 1998 Electroanalysis, 10, 355.

[23] Brown, R.J.C., Roberts, M.R., Brett, D.J.L. 2009 Anal. Chim. Acta, 635, 1.

[24] Attar, T., Harek, Y., Medjati, N., Larabi, L. 2011 Der Pharma Chemica, 2011, 3, 400.

[25] Attar, T., Harek, Y., Medjati, N., Larabi, L. 2012 International Journal of Analytical and Bioanalytical Chemistry, 2, 160.

[26] Mahajan, R.K., Walia, S., Tejinder, P., Sumanjit, S.K. 2005 Online Journal of Health and Allied Sciences, 4, 1.

[27] Inam, R., Somer, G. 1998 Talanta, 46, 1347.

[28] Attar, T., Harek, Y., Larabi, L. 2013 J. Korean Chem. Soc, 57, 568.

[29] Rodrigues, J.L., Bastista, L.B., Fillion, M., Passos, J.S.C., Mergler, D., Barbosa, F., 2009 Sci Total Environ, 407, 4168.

[30] Alimonti, A., Bocca, B., Mannella, E., Petrucci, F., Zennaro, F., Cotichini, R., D'lppolito, C., Agresti, A., Caimi, S., Forte, G. 2005 Ann Ist Super Sanita, 41, 181.

[31] Benes, B., Spevackova, V., Smid, J., Batariova, A., Cejchanova, M., Zitkova, L. 2005 Central European Journal of Public Health, 13, 202.

[32] Liu, J., Yang, H., Shi, H., Shen, C., Zhou, W., Dai, Q., Jiang, Y. 2010 Biol Trace Elem Res, 135, 31. 